\title{
TYROSINASE INHIBITION, 2,2-DIPHENYL-1-PICRYLHYDRAZYL RADICAL SCAVENGING ACTIVITY, AND PHYTOCHEMICAL SCREENING OF FRACTIONS AND ETHANOL EXTRACT FROM LEAVES AND STEM BARK OF MATOA (POMETIA PINNATA)
}

\author{
RANI SAURIASARI*, NUR AZIZAH, KATRIN BASAH
}

Department of Pharmacy , Faculty of Pharmacy, Universitas Indonesia, Depok, Indonesia. Email: sauri94@gmail.com

Received: 21 April 2017, Revised and Accepted: 13 July 2017

ABSTRACT

Objective: This study aims to investigate the potency of matoa as a tyrosinase inhibitor and antioxidant and also to identify the chemical compounds in the most active fraction and an ethanol extract from the leaves and stem bark of matoa.

Methods: The extracts were tested for their tyrosinase inhibitory activity by evaluating the formation of L-dopachrome at 490 nm. Antioxidant activity was tested using the 2,2-diphenyl-1-picrylhydrazyl (DPPH) method. The most active extract from liquid-liquid partition analysis was fractionated, and then, the assays were performed.

Results: The ethanol extract of leaves and stem bark of matoa showed weak anti-tyrosinase activity (percent inhibition was $24.54 \pm 0.22 \%$ and $21.93 \pm 0.57 \%$, respectively, final concentration $200 \mu \mathrm{g} / \mathrm{mL}$ ), but they showed strong DPPH radical scavenging activity (IC ${ }_{50}$ values were $6.11 \mu \mathrm{g} / \mathrm{mL}$ and $5.47 \mu \mathrm{g} / \mathrm{mL}$, respectively). The ethyl acetate fraction was the most active fraction with an IC ${ }_{50}$ value of $5.38 \mu \mathrm{g} / \mathrm{mL}$. Ethanol extract from the leaves and stem bark of matoa and the ethyl acetate fraction contains flavonoids, tannins, saponins, triterpenoids, and glycosides.

Conclusion: Matoa does not have potency as a tyrosinase inhibitor, but it has good antioxidant activity, although still lower than that of quercetin.

Keywords: Antioxidant, Tyrosinase inhibitor, 2,2-diphenyl-1-picrylhydrazyl, Matoa, Pometia pinnata.

(C) 2017 The Authors. Published by Innovare Academic Sciences PvtLtd. This is an open accessarticle under the CC BY license (http://creativecommons. org/licenses/by/4. 0/) DOI: http://dx.doi.org/10.22159/ajpcr.2017.v10s5.23105

\section{INTRODUCTION}

Melanin is a pigment that plays a role in determining skin color and protects the skin from ultraviolet (UV) radiation hazards, but the abnormal production or distribution of melanin can lead to hyperpigmentation, a disorder that causes dark spots or skin discoloration [1]. The process of melanin formation (melanogenesis) in the skin occurs in melanocyte cells. Tyrosinase is one of the major enzymes that catalyzes the process of melanin synthesis. Therefore, the excess production of melanin can be prevented or reduced by a tyrosinase inhibitor compound [2].

Tyrosinase inhibitors such as mercury, hydroquinone, and kojic acid have been widely used as skin whitening or hyperpigmentationpreventing materials, but the study results have revealed that these compounds are toxic and even can cause cancer [3]. Another substance that can affect the synthesis of melanin is free radicals. Free radicals can originate outside the body and enter through sources such as UV radiation, pollution, or food. It can also come from metabolic processes or enzymatic oxidation in the body, including from the process of melanogenesis. Free radicals can cause DNA damage, induce melanocyte proliferation, and increase melanin production, leading to hyperpigmentation [4]. The negative effects can be overcome by antioxidant compounds. The antioxidants can reduce or inhibit the free radicals that might otherwise lead to excess melanin formation. Some examples of antioxidant compounds used as inhibitors of melanogenesis include vitamin $\mathrm{C}$ and reduced glutathione [5].

The side effects from the use of toxic or carcinogenic compounds as inhibitors of melanogenesis are an impetus to search for alternative active ingredients that are safe for health, including those with natural ingredients. Results from the previous studies showed that some plants known to have good antioxidant activity also can act as tyrosinase inhibitors; for example, green tea, mulberry, and licorice extracts. The substances in these plants that have free radical scavenging activity and tyrosinase inhibitors are phenolic compounds [2,6].

The studies have found that some plants of the Sapindaceae family have good tyrosinase inhibitory ability besides antioxidant activity; these include Guioa villosa and Xanthoceras sorbifolia [7,8]. A type of plant from the Sapindaceae family that has not been utilized widely by Indonesians is matoa (Pometia pinnata, J.R. Forst \& G. Forst) [9]. The leaves and stem bark of matoa contain phenolic compounds, namely, flavonoids and tannins [10]. The stem bark of matoa's ability as a tyrosinase inhibitor has not been studied. Matoa leaves are also widely used in traditional medicine [11], but their activity as antioxidants or tyrosinase inhibitors has also not been studied. This study is conducted to determine the potential of matoa as a tyrosinase inhibitor and in free radical scavenging and to identify the class of compounds in the most active fraction in ethanol extracts of matoa leaves and stem bark.

\section{MATERIALS AND METHODS}

\section{Instruments}

The tools used in this study include maceration bottle, mechanical shaker (Janke \& Kunkel IKA), vacuum rotary evaporator (Janke \& Kunkel IKA and BuchiRotavapor R-205), freezer (Sanyo), UVV is spectrophotometry (PG Instruments Ltd. T8), Sonicator (Wiseclean), quartz cuvette (quartz cell), multichannel pipette 10-100 $\mu \mathrm{L}$ (Finnpippet), plate reader (BioTek Elx808), 96-well microplate, analytical scale (AND HR-200), oven (Memmert), silica gel plate F254 (Merck), crucible, furnaces, water bath (Imperial IV), Alcoholmeter, micro pipette 10-100 $\mu \mathrm{L}$ (Finnpippet) and 100-1000 $\mu \mathrm{L}$ (Eppendorf), pHmeter (Eutech Instruments), separating funnel (Duran), blender (Panasonic), and other glass wares.

\section{Materials}

This study used the simplicia of leaves and stem bark of the matoa plant ( $P$. pinnata, J.R. Forst and G. Forst) obtained from the environment 
surrounding the University of Indonesia, Depok. The simplicia has already been determined at the Indonesian Institute of Science (LIPI), the Center for Plant Conservation, and Bogor Botanical Gardens.

The chemical materials used in this study were 2,2-diphenyl-1picrylhydrazyl (DPPH) (Sigma Aldrich), quercetin (Sigma Aldrich), methanol p.a., (Merck), tyrosinase enzyme from fungi (Sigma Aldrich), L-DOPA (Sigma Aldrich), kojic acid (Sino Lion), distilled water, demineralized water, ethanol, $\mathrm{n}$-hexane, ethyl acetate, and technical methanol (Brataco), potassium dihydrogen phosphate (Merck), chloric acid (Merck), sulfuric acid (Mallinckrodt Chemicals), chloroform, boric acid, oxalic acid, iron (III) chloride (Merck), glacial acetic acid (Merck), aluminum chloride (Merck), benzene, potassium hydroxide (Merck), anhydrous acetic acid (Univar), and Molisch, Mayer, Dragendorff, and Bouchardat.

\section{Methods}

Research on anti-tyrosinase activity assay and DPPH radical scavenging of the fraction and ethanol extract of the leaves and stem bark of matoa (P. pinnata, J.R. Forst \& G. Forst) was carried out in several stages. This included materials preparation, extraction, testing the extract for the inhibition activity of tyrosinase and the radical scavenging activity of DPPH, parameter setting and active extract fractionation, DPPH radical scavenging activity of the fractions of the active extract, and phytochemical screening of the extract and the most active fraction.

\section{Materials preparation}

Fresh matoa leaves were collected, sorted, washed with clean running water, drained, and weighed before drying (1790 g). Fresh stems and branches were collected, sorted, washed with clean running water, and drained. The bark was removed from the stems or branches by slashing with a knife; then, the stem bark obtained was weighed (1420 g). Both materials were dried by air-cooling in the shade, followed by drying in a drying cupboard. Dry simplicia was weighed (leaf $990 \mathrm{~g}$ and stem bark $554 \mathrm{~g}$ ), resorted, and then powdered. The dry powder was stored in clean and dry containers.

\section{Extraction}

The extraction was done by the maceration method using a $70 \%$ ethanol solvent. Leaf powder $(572 \mathrm{~g})$ and stem bark powder $(550 \mathrm{~g})$ were each inserted into different amber bottles, and the $70 \%$ ethanol was added to $3-5 \mathrm{~cm}$ above the powder surface. The powder was macerated with the stirring aid (shaker) for $2 \mathrm{hrs,} \mathrm{and} \mathrm{then,} \mathrm{was} \mathrm{idle} \mathrm{for} \mathrm{up} \mathrm{to} 24 \mathrm{hrs}$. The extract obtained was separated from the pulp by filtration using a funnel and a white cloth/filter paper; then, the extract was stored in a container. The pulp was remacerated in the same way until the extract was almost colorless (the maceration was performed five times; the total volume of solvent used was as much as $9 \mathrm{~L}$ for leaf and $7.5 \mathrm{~L}$ for stem bark). Each extract was collected and then evaporated using a rotary vacuum evaporator at a temperature of $50-60^{\circ} \mathrm{C}$ and a speed of
$35 \mathrm{rpm}$, and then, placed in a water bath until a thick ethanol extract was obtained. The thick extract was then weighed, and the rendement was calculated [12].

\section{Tyrosinase inhibition test}

The tyrosinase inhibition test employed a method used by Masuda et al. [13] with some modifications. A solution of $50 \mathrm{mM}$ phosphate buffer, $\mathrm{pH}$ 6.5, up to $80 \mu \mathrm{L}$, was inserted into a 96-well microtiter plate, and $40 \mu \mathrm{L}$ of $10 \mathrm{mM} \mathrm{L}-\mathrm{DOPA}$ solution and $40 \mu \mathrm{L}$ of $1000 \mathrm{mg} / \mathrm{mL}$ extract sample solution were added. Then, $40 \mu \mathrm{L}$ of tyrosinase solution was added and incubated at $37^{\circ} \mathrm{C}$ for 10 minutes. The absorption was measured with a microplate reader at a wavelength of $490 \mathrm{~nm}$. Tests for this sample solution included blanks, blank controls, and sample controls. The extracts with high tyrosinase inhibition were then tested with concentration variations of $125,250,500,750$, and $1000 \mu \mathrm{g} / \mathrm{mL}$.

\section{Antioxidant activity test using qualitative method of DPPH}

About $5 \mathrm{mg}$ each of ethanol extract of matoa leaf and stem bark were weighed and dissolved in $5.0 \mathrm{~mL}$ methanol to obtain a $1000 \mu \mathrm{g} / \mathrm{mL}$ concentration. Then, the solution was diluted to a concentration of $100 \mu \mathrm{g} / \mathrm{mL}$. Each solution extract was spotted on a silica gel F254 plate using a capillary tube and then sprayed with DPPH solution in methanol. The DPPH free radical inhibitory activity was characterized by the formation of yellow spots in a purple background [14]. The comparator used was quercetin.

Antioxidant activity test using the quantitative method of DPPH The antioxidant activity test of the extract was performed quantitatively according to the Blois method (1958) using UV-visible spectrophotometry [15].

\section{RESULTS AND DISCUSSION}

The sociodemographic characteristics of the respondents (leaflet group and SMS reminders group) are listed in Table 1 . The largest percentage of participants were aged 20-35 years, were well educated Sekolah Lanjutan Tingkat Atas -Perguruan Tinggi, and were not working. The result of the statistical analysis between the two intervention groups showed that there were no differences regarding each variable.

\section{Tyrosinase inhibition test}

Kojic acid was used as a positive control and obtained an $\mathrm{IC}_{50}$ of $6.63 \mu \mathrm{g} / \mathrm{mL}$. The range of $\mathrm{IC}_{50}$ values of kojic acid was obtained from several previous studies, ranging from 4.35 to $7.18 \mu \mathrm{g} / \mathrm{mL}$ [16-19], indicating that the test method performed could be used.

The solubility orientation of the extract in the phosphate buffer solvent ( $50 \mathrm{mM}, \mathrm{pH}$ 6.5) was then performed; $25 \mathrm{mg}$ of the thick ethanol extract of the matoa leaves and stem bark each were dissolved in a phosphate buffer and disonicated. Both extracts dissolved perfectly

Table 1: Percentage of DPPH scavenging and the $\mathrm{IC}_{50}$ value of the ethanol extract of matoa leaves and stem bark

\begin{tabular}{|c|c|c|c|c|}
\hline Sample & Final concentration $(\mu \mathrm{g} / \mathrm{mL})$ & $\%$ Scavenging & Linear regression equation & $\mathrm{IC}_{50}(\mu \mathrm{g} / \mathrm{mL})$ \\
\hline \multirow[t]{6}{*}{ Ethanol extract of matoa leaves } & 1.25 & $9.63 \pm 0.42$ & $\begin{array}{l}y=1.1784+7.9956 x \\
r=0.9949\end{array}$ & 6.11 \\
\hline & 2 & $17.50 \pm 1.10$ & & \\
\hline & 2.5 & $23.71 \pm 0.64$ & & \\
\hline & 3.75 & $29.53 \pm 1.92$ & & \\
\hline & 5 & $40.57 \pm 0.85$ & & \\
\hline & 6.25 & $51.21 \pm 0.12$ & & \\
\hline \multirow[t]{6}{*}{ Ethanol extract of matoa stem bark } & 1.25 & $13.23 \pm 0.8$ & $\begin{array}{l}y=2.5598+8.6723 x \\
r=0.9949\end{array}$ & 5.47 \\
\hline & 2 & $19.58 \pm 1.27$ & & \\
\hline & 2.5 & $26.41 \pm 1.24$ & & \\
\hline & 3.75 & $31.80 \pm 0.99$ & & \\
\hline & 5 & $47.76 \pm 0.48$ & & \\
\hline & 6.25 & $56.53 \pm 1.81$ & & \\
\hline
\end{tabular}

DPPH: 2,2-diphenyl-1-picrylhydrazyl 
in the phosphate buffer. The main extract solution was then tested for inhibition of tyrosinase.

The inhibition percentage of the ethanol extract of matoa leaves and stem bark with a final concentration of $200 \mu \mathrm{g} / \mathrm{mL}$ was $24.54 \pm 0.22 \%$ and $21.93 \pm 0.57 \%$, respectively (Fig. 1). The value of the inhibition percentage showed that the inhibitory ability of the tyrosinase of the ethanol extract of matoa leaves and stem bark was much weaker than that of kojic acid $(6.63 \mu \mathrm{g} / \mathrm{mL})$.

The matoa leaves and stem bark were known to contain phenolic compounds, but the tyrosinase inhibitory ability of the ethanol extract of both simplicia was much weaker than that of kojic acid. This might be due to the structure of the phenolic compounds contained in the extract. The tyrosinase inhibitory ability of the phenolic compounds was strongly influenced by the structure of the phenolic compounds. The amount and position of the hydroxyl groups of the B ring and the substitution of the hydroxyl groups as well as their steric constraints played an important role in the inhibition of phenolic compounds against tyrosinase activity [20]. For example, quercetin and kaempferol were known to be flavonoid compounds with activity as tyrosinase inhibitors [6]. The ethanol extract of matoa leaf also contained two flavonoid compounds, but the percentage of the inhibition was low. This might be because the two compounds in the matoa leaf were present in the form of glycosides, which eliminated their ability to inhibit tyrosinase. The sugar molecule attached to the 3-hydroxy group of the flavonoids would prevent the binding of the flavonoid compound on the active side of the tyrosinase, so it could not inhibit the enzyme activity [6].

\section{Antioxidant activity test with the qualitative method of DPPH}

The purple DPPH radicals changed color to yellow after reacting with antioxidant compounds. The strength of antioxidant activity of the tested sample was seen from the intensity of the color of the yellow spot in a purple background. The higher the intensity of the yellow color, the higher the antioxidant activity of the sample [17].

The test results showed that the yellow spots for the ethanol extract of the matoa leaf and stem bark of matoa had quite high color intensity, but the intensity was less than that of quercetin. The color intensity from the spots of the two extracts was almost the same (Fig. 2). This showed that the antioxidant activity strength of both extracts was quite high and almost the same, but their antioxidant strength was still lower than that of quercetin.

\section{Antioxidant activity test by quantitative method of DPPH}

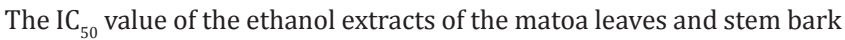
was $6.11 \mu \mathrm{g} / \mathrm{mL}$ and $5.47 \mu \mathrm{g} / \mathrm{mL}$, respectively (Table 1 ). Based on the $\mathrm{IC}_{50}$ values obtained, the two extracts were classified into a very strong DPPH radical scavenging activity group, but this was still lower than the strength of quercetin ( $\mathrm{IC}_{50} 1.11 \mu \mathrm{g} / \mathrm{mL}$ ). The test compounds could be categorized according to the strength of the antioxidant into groups of various intensity according to the $\mathrm{IC}_{50}$ value. Antioxidant activity with an $\mathrm{IC}_{50}$ value of less than $50 \mathrm{ppm}$ was categorized as very strong, strong if the $\mathrm{IC}_{50}$ value was between 50 and $100 \mathrm{ppm}$, moderate if the value of the $\mathrm{IC}_{50}$ was $101-250 \mathrm{ppm}$, and weak if the $\mathrm{IC}_{50}$ value was greater than $500 \mathrm{ppm}[21]$

The very strong radical scavenging activity was caused by the content of the phenolic compounds (flavonoids and tannins) in the matoa leaves and stem bark. Screening results performed by Cho et al. showed that the methanol extract of some Rosaceae plant family materials had a DPPH radical scavenging activity that was very strong, with an $\mathrm{IC}_{50}$ value below $10 \mu \mathrm{g} / \mathrm{mL}$, and the main content in the plant extract was the polyphenolic compounds [22]. The polyphenolic compounds isolated from the plant had been investigated to have strong DPPH scavenging activity, including condensed tannins, quercetin, catechins, and kaempferol.

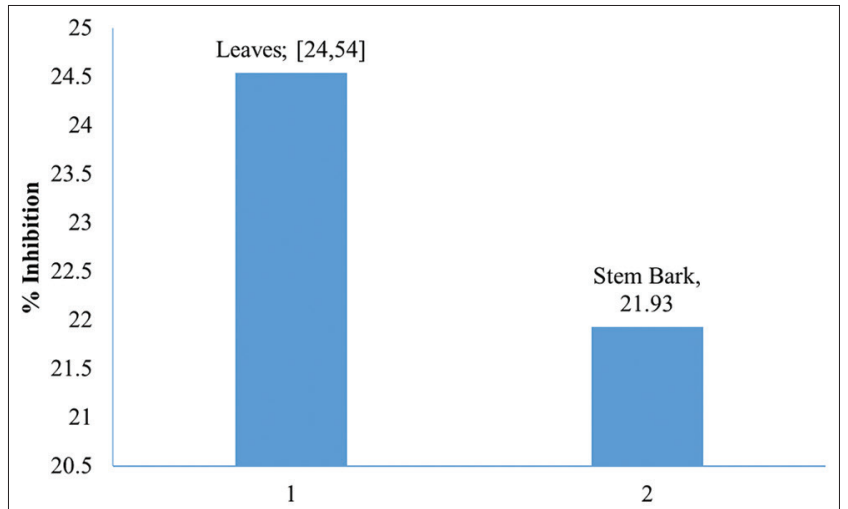

Fig. 1: Bar chart of the inhibition of the ethanol extract of the matoa leaves and stem bark against the tyrosinase activity percentage

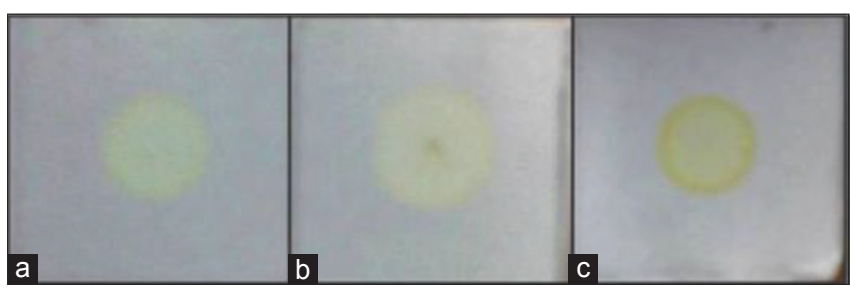

Fig. 2: The 2,2-diphenyl-1-picrylhydrazyl qualitative test results (a) the ethanol extract of matoa leaf, (b) the ethanol extract of matoa stem bark, and (c) quercetin

One of the mechanisms for controlling excessive melanin production in hyperpigmentation was the provision of antioxidants. The antioxidants could reduce free radicals in melanocytes to prevent the activation of the process of melanogenesis [6]. The ethanol extract of matoa leaves and stem bark had very strong free radical scavenging (DPPH) activity that was potentially used in the prevention of hyperpigmentation.

Antioxidant activity test of the matoa stem bark extract fractions The ethanol extract of matoa stem bark, as much as $65 \mathrm{~g}$, was fractionated by liquid-liquid partition using a separating funnel. Using solvents with increasing polarity from non-polar (n-hexane), semipolar (ethyl acetate), and polar (methanol) solvents, $0.14 \mathrm{~g}$ n-hexane fraction, $4 \mathrm{~g}$ ethyl acetate fraction, and $40.38 \mathrm{~g}$ methanol fraction were obtained. For each fraction obtained, the value of the fraction yield was calculated. The methanol fraction had the greatest weight, so it was suspected that the largest content in the ethanol extract of the matoa stem bark was a polar compound.

The fractions obtained from the fractionation of the ethanol extract of the matoa stem bark were then tested for their antioxidant activity by the DPPH method. The antioxidant activity test for the extract used the same method.

The ethyl acetate fraction showed the highest intensity of yellow spot color compared with the n-hexane and methanol fractions (Fig. 3). This showed that qualitatively the fraction with the best DPPH scavenging activity was the ethyl acetate fraction. This result was in accordance with the quantitative test, where the ethyl acetate fraction gave the highest percentage of DPPH radical scavenging (Fig. 4). The $\mathrm{IC}_{50}$ value of the ethyl acetate fraction was $5.38 \mu \mathrm{g} / \mathrm{mL}$ (Table 2 ). Based on this result, the ethyl acetate fraction had a very strong DPPH radical scavenging activity, although still lower than that of quercetin ( IC $_{50}$ of $1.11 \mu \mathrm{g} / \mathrm{mL}$ ). The ethyl acetate fraction had an $\mathrm{IC}_{50}$ value that was slightly lower than the $\mathrm{IC}_{50}$ value of the original extract, $5.47 \mu \mathrm{g} / \mathrm{mL}$. This might be because the compounds that had high activity as DPPH radical scavenger in the matoa stem bark extract mostly presented in the ethyl acetate fraction. This might be because the compounds had high activity as DPPH radical 
Table 2: Percentage of DPPH scavenging and $\mathrm{IC}_{50}$ value of the ethyl acetate fraction of matoa stem bark extract

\begin{tabular}{lllll}
\hline Sample & Final concentration $(\mu \mathrm{g} / \mathrm{mL})$ & \% Scavenging & Linear regression equation & IC $_{50}(\boldsymbol{\mu g} / \mathbf{m L})$ \\
\hline Ethyl acetate fraction of matoa stem bark & 1.25 & $14.89 \pm 1.61$ & $\mathrm{Y}=6.9112+8.3033 \mathrm{x}$ & 5.38 \\
& & & $\mathrm{r}=0.9939$ & \\
& 2 & $23.46 \pm 0.77$ & \\
& 2.5 & $29.91 \pm 0.79$ & \\
& 3.75 & $39.82 \pm 0.27$ & \\
& 5 & $47.96 \pm 2.26$ & \\
& 6.25 & $57.72 \pm 0.24$ & \\
\hline
\end{tabular}

DPPH: 2,2-diphenyl-1-picrylhydrazyl

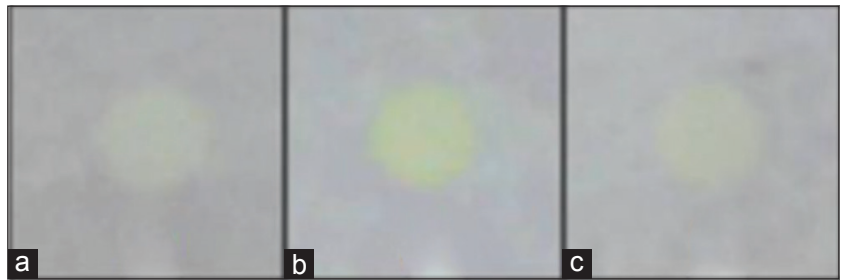

Fig. 3: The qualitative 2,2-diphenyl-1-picrylhydrazyl test results in the ethanol extract fractions of the matoa stem bark: (a) The n-hexane fraction, (b) the ethyl acetate fraction, and (c) the methanol fraction

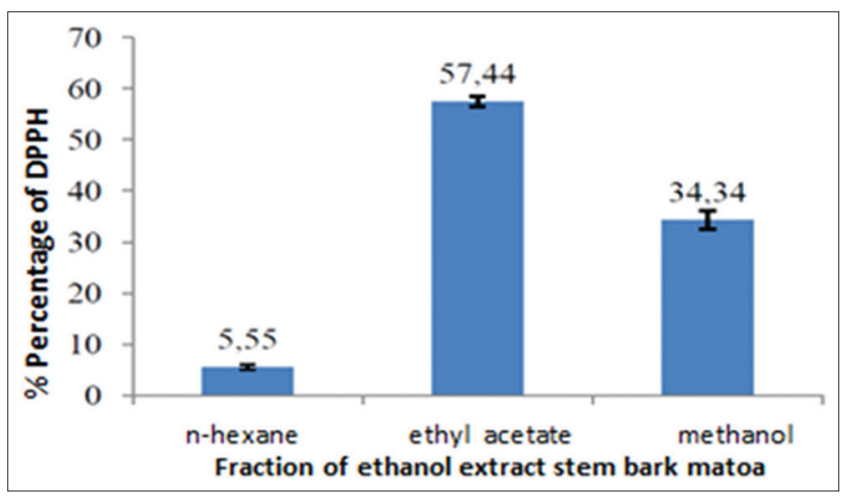

Fig. 4: Percentages of DPPH scavenger fractions of the ethanol extract of the matoa stem bark

dampers in the matoa stem bark extract mostly presented in the ethyl acetate fraction. The compound had a higher concentration in the fraction, resulting in a higher level of DPPH scavenging.

The result of phytochemical screening obtained was in line with the results of research conducted by Suedee et al. and Mataputuna et al. which showed that the matoa leaves and stem bark contained flavonoids, tannins, saponins, triterpenoids, and glycosides [12,23]. The ethanol extract of matoa leaves also contained steroid compounds, but the concentration might have been too small to detect in the tests performed in this study. The chemical compounds in the ethyl acetate fraction were flavonoids, tannins, saponins, triterpenoids, and glycosides.

The secondary metabolite compounds in the extract determined the activity of the extract, both the tyrosinase inhibition and the free radical scavenging activities (antioxidants). The ethanol extract of the leaves, the ethyl acetate fraction, and the ethanol extract of matoa stem bark had very strong DPPH radical scavenging activity. This might be due to the content of the phenolic compounds in both the extracts and the ethyl acetate fraction. The polyphenolic compound was known to have good radical scavenging activity [4]. In addition, the polyphenolic compound was known to have activity as a tyrosinase inhibitor, but this activity was strongly influenced by the structure of the polyphenolic compound [2]. Polyphenolic compounds in the matoa leaves, based on the previous research, were proanthocyanidin A2, epicatechin, kaempferol-3-0rhamnoside, and quercetin-3-0-rhamnoside [12], while the matoa stem bark contained leucoanthocyanidin and condensed tannins [10]. These compounds had a high DPPH scavenging activity, such as quercetin $\left(\mathrm{IC}_{50}=0.83 \mu \mathrm{g} / \mathrm{mL}\right)$ and kaempferol $\left(\mathrm{IC}_{50}=1.87 \mu \mathrm{g} / \mathrm{mL}\right)($ Cho et al., 2003). Almost all tannin compounds had been studied to show high DPPH scavenging activity in a small concentration range [24]. The compound content caused the matoa leaves and stem bark extracts to have very strong DPPH scavenging activity, but both extracts did not have good tyrosinase inhibitory ability. This might be because the polyphenolic compounds in both extracts were mostly in the form of glycosides, which gave the polyphenolic compounds less ability to bind and inhibit the action of tyrosinase enzyme [20].

\section{CONCLUSION}

The ethanol extracts of matoa leaves and stem bark have a weak tyrosinase inhibitory ability. The ethyl acetate fraction of the ethanol extract of the stem bark of matoa has a very strong DPPH radical scavenging activity, although it is still below that of the quercetin. The ethanol extract of matoa leaves and the ethanol extract and ethyl acetate fraction of matoa stem bark contain flavonoids, tannins, saponins, triterpenoids, and glycosides.

\section{REFERENCES}

1. Park KC, Huh SY, Choi HR, Kim DS. Biology of melanogenesis and the search for hypopigmenting agents. Dermatol Sin 2010;28(2):53-8.

2. Chang TS. An update review of tyrosinase inhibitors. Int J Mol Sci 2009;10(6):2440-75.

3. Momtaz S, Mapunya BM, Houghton PJ, Edgerly C, Hussein A, Naidoo S, et al. Tyrosinase inhibition by extracts and constituents of Sideroxylon inerme L. Stem bark, used in South Africa for skin lightening. J Ethnopharmacol 2008;119(3):507-12.

4. Balakrishnan KP, Nithya N, Arun D. Screening of some medicinal plants for their anti-tyrosinase and antioxidant activities. Int J PharmTech Res 2011;3(2):1107-12.

5. Huang HC, Hsieh WY, Niu YL, Chang TM. Inhibition of melanogenesis and antioxidant properties of Magnolia grandiflora L. Flower extract. BMC Complement Altern Med 2012;12:72.

6. Kim YJ, Uyama H. Tyrosinase inhibitors from natural and synthetic sources: Structure, inhibition mechanism and perspective for the future. Cell Mol Life Sci 2005;62(15):1707-23.

7. Magid AA, Voutquenne-Nazabadioko L, Bontemps G, Litaudon M, Lavaud C. Tyrosinase inhibitors and sesquiterpene diglycosides from Guioa villosa. Planta Med 2008;74(1):55-60.

8. Zhang H, Zhou Q. Tyrosinase inhibitory effects and antioxidative activities of saponins from Xanthoceras sorbifolia nutshell. PLoS One 2013;8(8):e70090.

9. Uji T. Diversity of Indonesian fruits and their potency. Biodiversitas 2007;8(2):157-67.

10. Thomson LA, Thaman RR. Pometia pinnata G.R. Forst \& G.Forst (tava). Ver. 2.1. In: Elevitch CR, editor. Species Profiles for Pacific Island Agroforestry. Holualoa: Permanent Agriculture Resources (PAR) Publishers; 2006.

11. Lim TK. Fruits. Edible Medicinal and Non-Medicinal Plants. Vol. 6. London: Springer; 2013.

12. Suedee A, Tewtrakul S, Panichayupakaranant P. Anti-HIV-1 integrase compound from Pometia pinnata leaves. Pharm Biol 2013;51(10):1256-61.

13. Masuda T, Yamashita D, Takeda Y, Yonemori S. Screening for tyrosinase 
inhibitors among extracts of seashore plants and identification of potent inhibitors from Garcinia subelliptica. Biosci Biotechnol Biochem 2005;69(1):197-201.

14. Saha MR, Hasan SM, Akter R, Hossain MM, Alam MS, Alam MA, et al. In vitro free radical scavenging activity of methanol extract of the leaves of Mimusops elengi Linn. Bangladesh Soc Vet Med 2008;6(2):197-202.

15. Blois MS. Antioxidant determinations by the use of a stable free radical. Nature 1958;181:1199-200.

16. Lee YS, Park JH, Kim MH, Seo SH, Kim HJ. Synthesis of tyrosinase inhibitory Kojic acid derivative. Arch Pharm 2006;339(3):111-4.

17. Azmi NU. Uji penghambatan aktivitas tirosinase dan identifikasi golongan senyawa kimia ekstrak dan fraksi teraktif daun Johar (Cassia siamea Lamk.). Thesis. Depok: Universitas Indonesia; 2013.

18. Mapunya MB, Hussein AA, Rodriguez B, Lall N. Tyrosinase activity of Greyia flanaganii (Bolus) constituents. Phytomedicine 2011;18(11):1006-12.

19. Zheng ZP, Tan HY, Chen J, Wang M. Characterization of tyrosinase inhibitors in the twigs of Cudrania tricuspidata and their structure- activity relationship study. Fitoterapia 2013;84:242-7.

20. Loizzo MR, Tundis R, Menichini F. Natural and synthetic tyrosinase inhibitors as anti-browning agents: An update. Compr Rev Food Sci Food Safe 2012;11:378-98.

21. Jun M, Fu HY, Hong J, Wan X, Yang CS, Ho CT. Comparison of antioxidant activities of isoflavones from kudzu root (Pueraria labata Ohwi). J Food Sci 2003;68(6):2117-22.

22. Cho EJ, Yokozawa T, Rhyu DY, Kim SC, Shibahara N, Park JC. Study on the inhibitory effects of Korean medicinal plants and their main compounds on the 1,1-diphenyl-2-picrylhydrazyl radical. Phytomedicine 2003;10(6-7):544-51.

23. Mataputuna SP, Johnly AR, Julius P. the activity of $\alpha$-glucosidase inhibitory from extract of the matoa (Pometia pinnata Spp.) stem bark as antihyperlipidemic agent. JMUO 2013;2(2):119-23.

24. Yokozawa T, Chen CP, Dong E, Tanaka T, Nonaka GI, Nishioka I. Study on the inhibitory effect of tannins and flavonoids against the 1,1-diphenyl-2 picrylhydrazyl radical. Biochem Pharmacol 1998;56(2):213-22. 